\title{
Kamu Yönetimi Disiplininin Değişim Sürecinde Dwight Waldo’nun Rolü
}

\author{
Dwight Waldo's Role in The Change Process of Public Administration Discipline
}

\section{Bekir PARLAK}

Prof. Dr., Bursa Uludă̆ Üniversitesi, İ̈BF,

Siyaset Bilimi ve Kamu Yönetimi Bölümü,

bparlak21@gmail.com

https://orcid.org/0000-0001-8919-6481

\section{Sevil BINCAN}

Bilim Uzmanı, Uludă̆ Üniversitesi, SBE, sevilbincan.10@hotmail.com

https:Ilorcid.org\0000-0001-6468-2651
Makale Başvuru Tarihi: 01.10.2019

Makale Kabul Tarihi: 29.12.2019

Makale Türü: Araştırma Makalesi

ÖZET

\begin{abstract}
Anahtar
Kelimeler:

Yeni Kamu

Yönetimi Hareketi.

Dwight Waldo,

Kamu Yönetimi,

Dwight Waldo, Yeni Kamu Yönetimi Hareketi (YKYH)'nin tohumlarını atarak kamu yönetimine yeni bir kimlik kazandirmıştır. Bunun yanı sıra kamu yönetimini teorik bir perspektifle inceleyen ve siyaset bilimiyle arasındaki ilişkileri açıklayan eserlerinin bulunması, bürokrasi-demokrasi iliş̧isine bütünsel bir analiz getiren çalışmalar yürütmesi gibi nedenlerden dolayı D. Waldo kamu yönetimi disiplininde önemli bir figür haline gelmiştir. D.Waldo; tüm eleştirilere rağmen klasik yaklaşımın öncüleri tarafindan ileri sürülen siyaset yönetim ayrımına karşı çıkmışıtır. Ona göre siyaset ile yönetim birbiriyle etkileşim içinde bulunan bir bütündür. D.Waldo'nun bu görüşü günümüz kamu yönetimi anlayışını etkilemektedir. Çalışmada, kamu yönetimi disiplinine bu kapsamda katkılar sağlayan D. Waldo'nun eserleri ve günümüz kamu yönetimi anlayışının șekillenmesinde rol oynayan görüșleri değerlendirilmektedir. Calışmada D. Waldo'nun ortaya koyduğu bazı eserleri analiz edilmekte ve bu kapsamda D. Waldo'ya yöneltilen eleştirilere yer verilmektedir.
\end{abstract}

Keywords:

New Public

Administration

Movement,

Dwight Waldo,

Public

Administration,

\section{ABSTRACT}

Dwight Waldo has introduced a new identity to public administration by sowing the seeds of the new Public Administration Movement. In addition to this, D. Waldo had become an important figure in the public administration discipline due to the existence of works that explain the relationship between the political science and the public administration with a theoretically perspective, carrying out a holistic analysis of the relationship between bureaucracy and democracy. Also, D. Waldo; in spite of all the criticism, he rejected the distinction between politics and administration which was put forward by the pioneers the classical approach. According to him, politics and management are a whole that interacts with one another. This view of D. Waldo influences the understanding of contemporary public administration. In this study, D. Waldo's works, which contribute to the discipline of public administration in this context, and their views that play a role in shaping today's understanding of public administration are evaluated. The study, some of D. Waldo's works are analyzed and this context are included criticisms of D. Waldo. 


\section{GIRISS}

Dinamik bir mekanizmaya sahip olan kamu yönetimi disiplini, belli dönemlerde meydana gelen siyasal, toplumsal ve ekonomik değişimler ekseninde farklı kimliklere bürünmektedir. Bu değişim süreci boyunca kamu yönetimi disiplininde geleneksel yaklaşım, yeni kamu yönetimi hareketi, yeni kamu işletmeciliği gibi farklı yaklaşımlar karşımıza çıkmaktadır. Ortaya çıkan her yaklaşım; disipline yeni teoriler, kavramlar, unsurlar kazandırmaktadır. Örneğin; YKYH' nin öncüsü D. Waldo değerler temelinde şekillenen Demokratik Yönetim kuramını savunmaktadır. Ayrıca; 1968 yılında D. Waldo tarafindan organize edilen I. Minnowbrook Konferansında doğan bu hareket ile sosyal adalet, etik yönetim, katılımcılık, demokratik yönetim gibi değerlere önem atfedilmektedir.

Kamu yönetimi disiplininde ön plana çıkan her yaklaşımın kendinden önce gelen yaklaşımın eksiklerini tamamlamak, mevcut olan ve çözülemeyen problemlere çözüm önerileri getirebilmek adına ortaya çıtığını söylemek mümkündür. Örneğin; 1960'l1 yılların sonlarına doğru Amerika Birleşik Devletleri (ABD)'nin içinde bulunduğu olumsuz koşullara klasik kamu yönetimi anlayışının çözüm önerilerinde bulunamamasının sonucu olarak YKYH karşımıza çıkmaktadır. Ayrıca bu hareketin öncülerinden olan Waldo; klasik görüş tarafından ileri sürülen siyaset-yönetim ayrımına, bilimsel yönetim ilkelerine karşı çıkmıştır. Görüldüğü üzere toplumsal taleplerin ve beklentilerin karşılanamaması bir kimlik bunalımının yaşanılmasına neden olmakta ve değişen koşullara uyum sağlayabilmek adına uzun yıllardır süregelen yeni model arayışları devam etmektedir. Bu bağlamda kamu yönetimi disiplinine YKYH ile yeni bir bakış açısı kazandıran D. Waldo kamu yönetimini bir süreç ve bir disiplin alanı olarak ifade etmektedir. D. Waldo sorgulayıcı bir analizle eserlerinde kamu yönetimine ilişkin kavramları, unsurları, problemleri incelemekte ve demokrasi gibi değerlere atıfta bulunmaktadır. D. Waldo; The Administrative State (İdari Devlet) adlı eserinde geleneksel kamu yönetimi anlayışının bazı savlarını (ekonomi ve verimlilik, bilimsel yönetim ilkeleri, siyaset- yönetim ayrımı) eleştirel bir bakış açısıyla ele almakta, Development Of Theory Of Democratic Administration (Demokratik Yönetim Kuramının Gelişimi) adlı makalesinde demokrasi nedir? Sorusunu yanıtlamaya çalışarak demokratik yönetim anlayışına atıfta bulunmakta, The Study Of Public Administration (Kamu Yönetiminin İncelenmesi ) adlı eserinde ise kamu yönetimi nedir? kamu yönetimi disiplininin kategorileri nelerdir? gibi sorulara cevap aramaktadır.

Çalışmada, D. Waldo'nun kamu yönetimi disiplinine ilişkin ileri sürmüş olduğu temel görüşleri ve bazı eserleri referans alınarak kamu yönetiminin yeni bir kimlik kazanmasındaki rolü incelenilmiş, bu görüş ve eserlerin günümüz kamu yönetimi anlayışının şekil almasındaki rolü analiz edilmeye çalışılmıştır. Bu kapsamda çalışma birincil ve ikincil kaynaklara dayalı nitel bir araştırmadır.

\section{YENI KAMU YÖNETIMI HAREKETININ ÖNCÜSÜ DWIGHT WALDO'NUN ÇALIŞMALARINA İLIŞKİN GENEL BİR DEĞERLENDİRME}

\subsection{Yeni Kamu Yönetimi Hareketi}

ABD' de bazı kesimlerin (zencilerin) sosyal refahtan pay alamaması -1rk ayrımcılığı-, cinsiyet temelli eşitsizlik, kentsel ayaklanmalar gibi bazı olumsuz durumların yaşanması 1960'ların ortalarından itibaren temel kurumlara yönelik güvenin sarsılmasina neden olmuştur. Bu tür problemler güncel toplumsal ve idari sorunlara dayal1, insancıl ve sosyal adalet, eşitlik kapsamında insiyatif kullanan bir kamu idare ihtiyacının gerekliliğini gözler önüne sermiştir (Özgür, 2003:189). D. Waldo; yaşanılan bu olumsuzluklara çözüm üretilebilmesi adına 1968 yılında Public Administration Review'de yayınlanan "Public Administration in a Time of Revolutions" adl çalışmasında kamu yönetiminin bazı sorumluluklar yüklenmesi gerektiğine değinir. D.Waldo’ya göre;

"Kamu yönetiminin ortaya koymuş olduğu başarı ve başarısızlıklar, gündemdeki bir çok problemin baş göstermesinde etkili olmuştur. Dolaylstyla en kisa sürede yöneticilerin bu problemlere çözüm önerilerinde bulunması gerekmektedir. Ĕger, kamu yönetimi bilgi açısından gerekli donanıma sahipse, yaşanabilir bir çevrenin oluşturulmasında, şiddetin ve yoksulluğun mümkün olabildiğince azaltılmasında, eşitlik ve adaletin sağlanmasında aktif bir konumda yer alması gerekmektedir" (Waldo 1968'den akt.: Atalay, 2008:131).

Ayrıca D. Waldo editörü olduğu Public Administration Review Dergisi'nde yayınladığı bu çalışma ile yaşanılan problemlere karşın kamu yönetimi dünyasını duyarsız olmakla eleştirmekte ve okuyuculara seslenerek bu problemleri müzakere etmeye çağırmaktadır. D.Waldo’ya göre belirtilen problemler ekseninde ortaya çıkan bu 
hareket; toplumsal ve siyasal mayalanmanın etkisiyle gençlerin bir tepkisi ve Marksist olmayan solun karşı kültürünün bir kısmıdır (Durmuş, 2017:417).

1960'larda ABD'de yaşanan bu problemleri anlama ve açıklamaya yardımcı kavram, teori ve yaklaşımları geliştirecek bir zemin hazırlama arayışlarıyla kapsamında formüle edilen YKYH sorunların çözümünde özellikle sosyal adalet, katılımcılık, eşitlik, demokrasi gibi faktörleri ön plana çıkarmaktadır (Tozlu, 2017:331). Klasik kamu yönetimi anlayışının mevcut sorunlara çözüm üretememesini eleştiren YKYH'nin D. Waldo, George Frederickson, Frank Marini ve Henry Lambright gibi temsilcileri sosyal adalet- toplumsal eşitlik arayış1 içerisindedir. Onlara göre etnik ayrımcılığa, yoksulluğa ve şiddete karşı mücadele gibi konular kamu yönetimi alanında ön plana çıkmalıdır. YKYH savunucuları; klasik yaklaşımın temel aldığı etkinlik, verimlilik ve tasarruf anlayışını eleştirmekte ve siyaset yönetim dikotomisini reddetmektedir (Hergüner, 2015:79). Özetle; YKYH'ni;

\section{" Kamu yönetimi disiplininin öncülerinden biri olan Dwight Waldo'nun 1960'ların sonlarına doğru organizasyonluğunu üstlendiği Minnowbrook konferansının ardından gelişen ve kamu yönetiminin jön Türkleri (young Turks) şeklinde adlandırllan, içlerinde H. George Frederickson gibi isimlerin de bulunduğu 30'lu yaşlardaki genç akademisyenlerce ileri sürülen; temsiliyet, demokrasi, toplumsal eşitlik, sorumluluk gibi prensipleri esas alan akım",}

şeklinde tanımlayabiliriz (Hergüner, 2015:74). Timney' a göre; bu akademisyenler George Frederickson'un da konuların görüşebileceği ve tartışılabileceği "konferans içinde konferans" olarak adlandırdığı bir Minnowbrook geleneğini yaratmıştır (Timney, 2009:97).

\subsection{Minnowbrook Konferansları (1968-1988}

YKYH; D. Waldo'nun öncülüğünde modernizmin, liberalizmin ve faydacı ahlakın bazı savlarına eleştride bulunan genç kamu yönetimi akademisyen ve uygulamacılarının katılımıyla 1968 Eylül'ünde Syracuse Üniversitesi'nde gerçekleştirilen Minnowbrook Konferansıyla ortaya çıkmıştır (Ciğeroğlu ve Özgür, 2011:281). Sosyal eşitliğe değer verme ve bunu kamu programlarını yönetmede rehber olarak kullanmak Minnowbrook geleneğinin köklerini oluşturmaktadır. 1968'de düzenlenilen Minnowbrook I Konferansı'na katılan akademisyenler; kamu idarelerinin, verimlilik ve etkililiğe değer vermenin yanı sıra, kamu hizmetlerinin yönetiminde ve dağıtımında sosyal eşitlik değerinin vurgulanması gerektiğini ifade etmektedir. Daha geniş bir toplum için sosyal eşitlik konusunu gündeme getirmede başı çeken Minnowbrook I katılımcısı Frederickson toplumsal eşitliği kamu idaresinin geleceği için önemli bir odak noktası olarak tanımlamakta ve Amerikan demokrasisini eleştirmektedir (Gooden ve Portillo, 2011:61-62). Minnowbrook I Konferansı'na birkaçı hariç çoğu yardımcı doçent olan ABD'li otuz üç akademisyen katılmıştır. Katılımcılar arasında bir kadın akademisyen bulunmaktadır. Konferansta her ne kadar birbirinden farklı görüssler ileri sürülse de genel itibariyle mevcut sorunları mümkün olabildiğince kısa sürede çözüme kavuşturma isteği ön plana çıkmaktadır (Atalay, 2008:132133).

Minnowbrook I Konferansı'nın düzenlenildiği tarihten 20 yıl sonra 1988 yılında George Frederickson tarafından Minnowbrook II Konferansı organize edilmiştir. Minnowbrook II konferansı kamu yönetiminin değişen dönemlerini (1960-1980) kıyaslamak ve karşılaş̧ırmak amacıyla tasarlanmıştır. Bu konferansa kamu yönetimi, ekonomi, siyaset bilimi, sosyoloji, psikoloji, antropoloji, tarih alanlarından 68 akademisyen katılmıştır. 1988 Konferansı Syracuse, Kansas ve Akron Üniversiteleri tarafından finanse edilmiştir (Frederickson, 1989:95-99).

Minnowbrook II Konferansı'nda sosyal eşitlik, etik, insan ilişkileri, demokrasi ve kamu yönetiminin uzlaştırılması gibi birinci konferansta ön plana çıkan konuların yanı sıra liderlik, anayasal ve yasal perspektif, teknoloji, politika yapımı, ekonomik perspektif gibi konular da görüşülmüştür (Özgür, 2003:192). Minnowbrook I Konferansı ile temelleri atılan YKYH'nin ABD ile sınırlı kalması; yeni kamu yönetiminin ne olabileceği hususunda katılımcılar arasında yaşanılan bazı görüş ayrılıklarının sebep olduğu fikri dağınıklık yaşanılması; bürokratik sorunlara bürokratik çözümler üretilmesi, kültürel ve etnik çeşitlilik teorileri, feminist teori, çevre hakk1 teorilerinin Minnowbrook II Konferansı'nda tartışılmaması gibi eleştirilerde bulunulmuştur (Özgür, 2003:207-211). 


\subsection{Dwight Waldo'nun Hayatı}

D. Waldo, 1913 yılında ABD'nin Nebraska Eyaletindeki De Witt kasabasında dünyaya gelmiştir. Lise ögrenimini tamamladıktan sonra 1931 y1lında Nebraska Wesleyan Koleji'ne başlayan Waldo bir yıl sonra maddi yetersizlikler sonucunda öğrenimine Peru'da ki devlet üniversitesi olan Nebraska Eğitim Fakültesi'nde devam etmiştir. 1935 yılında mezun olduktan sonra Yale Üniversitesi'nde doktora yapmaya başlamıştır. Yale Üniversitesi'nde Profesör Francis Coker Amerikan siyaset teorisi açısından kamu yönetimi literatürüne bakmayı önerdi ve Waldo bu alanda hazırlamış olduğu doktora tezini (Daha sonra İdari Devlet adıyla kitap şeklinde yayınlanmıştır) 1942 yılında sunmuştur (Carroll ve Frederickson, 2001:2).

Doktorasını tamamlayan D. Waldo; İkinci Dünya Savaşının bitmesinin akabinde yardımcı doçent olarak akademide görev almaya başlamıştır. 1946-1967 yılları arasında Berkeley Üniversitesi'nde öğretim üyeliği yapan Waldo; 1958- 1967 yılları arasındaki süreçte de Berkeley Üniversitesi Hükümet Çalışmaları Enstitüsü’nün başkanlığını yapmıştır. Bu süre zarfında 1948 yılında kamu yönetiminin klasikleri arasında yer alacak olan İdari Devlet Kitabı'nın ilk baskısı çıkmıştır. D. Waldo; Berkeley Üniversitesinde ki koşulların değişmesinden dolayı buradan ayrılmış ve 1967-1979 yılları arasında Syracuse Üniversitesi'nde öğretim üyeliği yapmıştır (Sayman, 2006:8-9).

ABD'nin içinde bulunduğu sorunlara çözüm önerilerinde bulunabilmek adına 1968 yılında Minnowbrook I Konferansı'nın öncülüğünü yapmıştır. 1979 yılında ise Syracuse Üniversitesi'nden emekli olmuştur. D. Waldo; 1966-1971 arası dönemde Public Administration Review Dergisinin baş editörlügünü yürütmüştür (Özer, 2014:12). Ayrıca; 1963- 1983 yılları arasında ise Uluslararası İdari Bilimler Dergisi’nin editör kurulu üyesi olarak görev almıştır. Waldo akademik kariyer hayatı boyunca birçok ödül almıştır. Bologna Üniversitesi Gümüş Madalyonu, Nebraska Üniversitesi onursal doktora ödülü, Uluslararası Şehir-İlçe Yöneticiler Birliği'nden hayat boyu onursal üyelik, Amerikan Kamu Yönetimi Topluluğu'nun William E. Mosher ve Laverne Burchfield ödülleri, Berkeley'de Kaliforniya Üniversitesi'nin Berkeley Takdirnamesi bu ödüllerden bazılarıdır. Ayrıca D. Waldo'nun Ulusal Kamu Yönetimi Akademisi, Amerikan Kamu Yönetimi Derneği, Amerikan Siyaset Bilimi Derneği, Uluslararası Siyaset Bilimi Derneği gibi birçok derneğe de üyeliği bulunmaktadır (Durmuş, 2017:405). Yeni Kamu Yönetimi hareketinin öncülüğünü üstlenen D. Waldo 27 Ekim 2000 tarihinde vefat etmiştir.

\subsection{Dwight Waldo'nun Eserleri}

D. Waldo; yaşamı boyunca kamu yönetimi disiplinine ilişkin önemli eserler bırakmıştır. D. Waldo'ya ait eserlerden bazıları şunlardır; The Administrative State: a Study of The Political Theory of American Public Administration (İdari Devlet: Amerikan Kamu Yönetiminin Bir Siyasal Teori İncelemesi- 1948), Development of Theory of Democratic Administration (Demokratik Yönetim Kuramının Gelişimi- 1952), Ideas and Issues in Public Administration (Kamu Yönetiminde Fikirler ve Sorunlar- 1953), The Study of Public Administration (Kamu Yönetiminin İncelenmesi -1955), Perspectives On Administration (Yönetim Üzerine Bakış Açıları1956), Public Administration in Time of Turbulence (Türbülans Zamanında Kamu Yönetimi- 1971), The Enterprise of Public Administration (Kamu Yönetimi İşletmeciliği- 1980). Bu bölümde İdari Devlet, Demokratik Yönetim Kuramının Gelişimi ve Kamu Yönetiminin İncelenmesi adlı eserleri hakkında bilgi verilmektedir.

\subsubsection{The Administrative State (İdari Devlet)}

Eser; D. Waldo'nun 1942 y1linda tamamlanan Theoretical Aspects of the American Literature of Public Administration başlı̆̆ını taşıyan doktora tezinin devamı niteliğindedir. 1948 senesinde ise bu çalışma The Administrative State: A Study of the Political Theory of American Public Administration adiyla Ronald Press Company tarafindan kitap şeklinde basılmıştır (Atalay, 2008:28). Eser üç ana bölümden oluşmaktadır. Birinci bölümde "kamu yönetiminin yükseliş̧" başlığı altında geleneksel kamu yönetiminin maddi ve ideolojik arka planı hakkında bilgi vermekte, klasik yaklaşımı etkileyen akımlar, hareketler ve değerlere değinmekte ve son olarak bilimsel yönetim ve kamu yönetimi arasındaki ilişkiye (pozitivizm, kamu yönetimi üzerinde bilimsel yönetimin etkileri vb.) yer verilmektedir. İkinci bölümde ise; "siyaset felsefesinin problemleri" başlığı altında kim yönetmeli sorusunu yanıtlamakta, iyi yaşam ve güçler ayrılığına ilişkin görüşlerine yer vermekte; merkeziyetçiliğe karşı ademi merkeziyetçilik düşüncesini ön plana çıkarmaktadır. Son olarak; "bazı temel kavramlar: bir eleştiri" başlığı altında ise ekonomi ve verimliliğe; bilimsel yöntemlerin teori ve ilkelerine yönelik eleştirilerde bulunmaktadır (Waldo, 1948: vii-viii). 
D. Waldo eserde; "kamu yönetiminin evrensel geçerlilik ilkelerine sahip bir bilim olduğu iddialarına rağmen, Amerikan kamu yönetiminin, benzersiz ekonomik, sosyal, hükümete ve ideolojik gerçeklerle açıkça bağlantılı olan politik teorileri gelişstirilmesi”' gerekliliğini ifade etmektedir (Waldo, 1948:3).

D. Waldo geleneksel kamu yönetiminin maddi arka planı belirleyen faktörleri arasında; Büyük Toplum (sosyal refah devletinin yükselişi) anlayışı, doğal kaynakların israfı, İşletme Uygarlığı Düşüncesi, Şirket Devrimi, şehirleşme, Amerika'ya ait anayasal ve siyasal sistem, uzmanlaşma eğilimi, I. ve II. Dünya Savaşı, Büyük Refah ve Büyük Buhran yer almaktadır (Stivers, 2008:53). İdeolojik arka planı kısmında ise; demokrasi ve Amerika'nın misyonu, kurucu yasa, ilerleme (insanın rasyonel bir varlık olması ile onun insanlık yararına bir toplumu yeniden oluşturulabileceği düşüncesi) ve ilerlemecilik, verimlilik müjdesi (gospel of efficiency) ve bilim inanc1 faktörlerini ele almaktadır (Waldo, 1948:12).

D. Waldo; geleneksel yaklaşımı etkileyen akımlar arasında ilerleme çağını ve reform hareketine yer vermekte ve yaklaşımda ön plana çıkan değerlerin ise bireycilik, materyalizm, "barış, özgürlük ve eşitlik" ve iyi yaşam olduğunu ifade etmektedir. Ayrıca Waldo; pozitivizm, faydacılık ve pragmatizmin geleneksel yaklaşımın karar verme ve eylem aşamalarındaki felsefi bileşenleri olduğunu belirtmektedir (Atalay, 2008:43-44).

$\mathrm{O}$ eserde; kamu yönetimi literatürüne ilişkin teorisel açıdan incelemede bulunmaktadır. Kamu yönetimi hareketini Amerikaya ait siyasi yapılanma temelinde ele almıştır. D. Waldo; İdari Devlet tezinde siyaset-yönetim ayrımına ilişkin bir çözüm önerisi istenildiği takdirde; kamu yönetiminin bu konuda bir politika oluşturulması konusuna vurgu yapmıştır. Fakat; belirlenen politika; siyasal partiler, bölgesel politikaların yerine düzenin, ekonomikliğin, verimliliğin, etkin yönetimin politikası olması gerekmektedir (Özer, 2014:17-18).

Siyaset ve yönetimin bir bütün olduğunu öne süren Waldo; kuvvetler ayrılığının erkler arasında rekabetin aksine iş birliğini sağladığını savunmaktadır. Uygulanan bu yöntemle amaç siyaset ve yönetim arasındaki iş birliğini pekiştirmek ve yöneticilerin yönetim sürecine katılımını arttırmanın yollarının bulunmasını sağlamaktır (Atalay, 2008:49). Ona göre; siyaset ve yönetim birbiri ile içi içe geçmiş bir bütün olduğundan, siyaset- yönetim ayrımı düşüncesi kamu yönetimi disiplinine zarar vermekte, dolayısıyla bu düşüncenin terk edilmesi gerekmektedir (Sakl1, 2013:148).

\subsubsection{Development of Theory of Democratic Administration (Demokratik Yönetim Kuramının Gelişimi)}

D. Waldo'nun "Demokratik Yönetim Kuramının Gelişimi" adlı makalesi 1952 yılında The American Political Science Review dergisinde yayınlanmıştır. D. Waldo; bir anlam sorunu ile başa çıkabilmek için öncelikle demokrasi nedir? sorusunun sorulması gerektiğini belirtir. Demokrasinin araçsal ve ideal olmak üzere iki anlamı vardır. Araçsal anlamı temsilciler meclisi gibi demokratik kurumları işaret ederken; ideal anlamı ise değerler topluluğunu kapsamaktadır. Daha sonra makalede geniş bir demokrasi yorumunun geçerliliğini kabul etmektedir. Ona göre demokrasinin merkezinde bir değerler kümesi yatmaktadır. Elbette hem tarihsel hem de mantıksal olarak özgürlük, eşitlik ve kardeşlik üçlüsünün iyi bir örneği olabilir. Bu kavramlar olmaksızın, temsilci meclisler, medeni haklar, evrensel oy hakkı, bağımsız yargılar ve çağdaş demokrasinin bütün paradigması anlamsızdır (Waldo, 1952:82). D. Waldo; vatandaş konseyleri, öneri kutuları gibi demokratik ve katılımcı çalışmaların yaygınlaştırılması gerektiğine vurgu yapmaktadır. Bunun yanı sıra çoğunluğun yönetimi ile azınlığın haklarının korunmasına yönelik ilişkinin dengeli bir şekilde yürütülmesi gerektiğine atıfta bulunmaktadır (Özgür, 2004:205).

D. Waldo; makalesinde iki önerme bulunmaktadır. İlk önerme; ülkenin hükümet şeklinin demokrasi olması ile ilgilidir. İkinci önerme ise; siyaset- yönetim ayrımının ortadan kaldırılması gerektiğidir. Klasik yaklaşımın önde gelen isimlerinden W. Wilson'un savına göre demokrasi siyaset bilimi ile kamu yönetimi ise verimlilik kavramı ile yakından ilişkilidir. Waldo ise araç ve amaçların birbirinden ayrılamayacağını savunarak bu ayrıma karşı çıkmaktadır. Yerel farkların ve değerlerin dikkate alındığı gerekçesiyle; demokratik yönetim kuramı ademi merkeziyetçiliğe önem vermektedir. Ayrıca D. Waldo çalışmasında ABD’nin demokrasiyi uluslararası alana yaymadaki rolüne atıfta bulunmuştur (Sayman, 2006:73).

Makalede geleneksel yönetim anlayışına dair eleştirilerde yer almaktadır. Örneğin; D. Waldo değerlerin görmezden gelindiği olaysallolgusal değer vermenin mümkün olmadığını ileri sürmektedir (Overeem, 2008:37). Yönetimin merkezinde yer alan verimliliğin değer- nötr bir kavram olduğu ve daha da kötüsü demokrasiye karşıt olduğu görüşünü reddetmektedir. Verimliliğin değerlere nötr bir şekilde idare biliminin merkezine yerleştirilmiş olmasının nihilizme neden olacağını belirtmektedir (Waldo, 1952:97). Bu makale aynı zamanda kamu yönetimi disiplininde önemli bir yer edinmiş Simon- Waldo atışmasının da başlangıcını oluşturmaktadır. Waldo makalesinde Simon'un "Yönetsel Davranış" adlı eserini eleştirmektedir. Verimlik konusunda farklı bir bakış açısın geliştiren D. Waldo; Simon’un eserinin verimlilik esaslı çalışmalara geri dönmeye çağırdığını ileri 
sürmektedir (Kara, 2018:15). D. Waldo eserin (1952:97) 40. dipnotunda, mevcut tartışmada mevcut görüşün kendisinin karşısında olduğunu; değerlerin dışlandığı bir olgusal alanın olmadığını, karar vermek alternatifler arasından seçim yapmak ise, seçim yapmanın değerleri ortaya koymak anlamına geldiğini ve Simon'un yönetim yazınında önemli bir yeri olduğunu ancak bunu metodolojisinden bağımsız olarak çalıştığında ortaya koyduğunu belirtmektedir. Simon da bu eleştiriye The American Political Science Review dergisinde;

"Bay Waldo'nun varsayımlarının doğru veya yanlış olması bir yana; onunda içinde bulunduğu pek çok siyaset teorisyenleri gibi azarlayıcl, edebi, metaforik biçimde düşünmeye ve yazmaya devam edilirse siyaset felsefesinde nasl ilerleme kaydedileceğini bilemediğini"

ifade eden kısa bir yazıyla karşılık vermiştir (Simon vd., 1952:494'den akt.: Kara, 2018:16). Geçmişte olduğu gibi günümüzde de siyasal alan ile yönetsel alan bir bütünü oluşturmaktadır. Dolayısıyla D.Waldo ile Simon arasındaki bu atışmayı D. Waldo’nun kazandığını söylemek mümkündür.

\subsubsection{The Study of Public Administration (Kamu Yönetiminin İncelenmesi)}

D. Waldo'nun; The Study of Public Administration adlı eseri 1955 y1lında yayınlanmıştır. Eser; "kamu yönetimi nedir" (birinci bölüm), "yönetim çalışmalarının gelişimi" (ikinci bölüm), "çağdaş eğitim ve öğretim" (üçüncü bölüm), "kamu yönetimi çalışmasında eğilimler" (dördüncü bölüm), "idari çalışma ve sosyal bilimler" (beşinci bölüm), "idari çalışmada değer problemi”" (altıncı bölüm), "geçmişe bakış ve olasıllk" (yedinci bölüm) başlıkları olmak üzere yedi ana bölümden oluşmaktadır (Waldo, 1955).

Eserde de belirtildiği üzere; yayının amacı kamu yönetimi çalışmalarını anlamak ve değerlendirmektir. D. Waldo, kamu idaresinin hem bir insan faaliyeti hem de entelektüel bir disiplin olarak önemini ifade etmekte ve bunun içinde bazı önemli kavramları ve tartışmaları tanıtmakta; insan bilgisinin bazı mevcut sınırlarının bir görünümünü vermektedir. Bu kapsamda eser kamu yönetimi nedir? Kim çalışmalı ve neden? Çalışmanın veya disiplinin temel kategorileri nelerdir? Kamu idaresinin, diğer faaliyetler ve süreçlerle bir faaliyet ya da süreç olarak ilişkileri nelerdir? Kamu yönetimi ile diğer çalışmalar ve disiplinler arasındaki bir çalışma ya da disiplin arasındaki ilişkiler nelerdir? Çağdaş eğilimler nelerdir? gibi soruların cevapları ekseninde ele alınmaktadır (Waldo, 1955:vi). Bu çalışma kamu yönetiminin yani insan iş birliğinin bir aşamasının veya yönünün incelenmesine bir giriş olarak tasarlanmıştır. D. Waldo'ya göre insan iş birliği teknolojisinde özel teknolojiler var olmakla birlikte; bu teknolojilerin incelenmesine ya da bu teknolojilerin çalışılmasına dair kavramsal aygıtlar da vardır. Dolayısıyla toplumumuzda kamu yönetimi, teknolojinin içinde yer alan teknolojilerden biridir ve uygulamasında ve çalışmasında kendi özel kavramsal aygıtlarına sahiptir (Waldo, 1955:2).

D. Waldo eserinde kamu yönetimi nedir? sorusuna yanıt bulmaya çalışmaktadır: ona göre kamu yönetiminin iyi bir tanımı yoktur ya da belki iyi kısa tanımlamaları vardır ama iyi bir kısa açıklaması yoktur. Diğer bir ifadeyle kamu yönetiminin tek cümle veya tek paragraf tanımlarının doğrudan etkisi, aydınlanma ve uyarımdan ziyade zihinsel felç olarak nitelendirilebilir. Bunun nedeni, terimin ciddi bir tanımının kaçınılmaz olarak birkaç soyut kelime veya kelime öbeği içermesidir. Kamu yönetimini tanımlamada kullanılan soyut kelimeler ve ifadeler sadece diğer soyut kelimeler ve deyimlerle açıklanabilir ve süreçte "o" nun gerçekliği önemi buğulanır ve kaybolur. D. Waldo; bu açıklamasının ardından kamu yönetimine yönelik iki örnek vermektedir. İlki; kamu yönetimi, devletin amaçlarına ulaşmak için $\mathrm{X}$ erkeklerinin ve malzemelerinin organizasyonu ve yönetimidir. Diğeri ise; kamu yönetimi, devletin işlerine uygulanan yönetim ve sanat bilimidir. Bu tanımlamalarda; kendi içlerinde anlayışı ilerletmenin yardımcı olamamasının haricinde yanlış olan bir şey bulunmamaktadır. Bu tanımlar okuyucunun zihnindeki keskin kavramları ve canlı görüntüleri çağrıştırabilir. Ancak bu durumun gerçekleşmemesi durumunda her kelime üzerinde bulmaca çözmek yerine açılamaların, tasvirlerin ve yorumlar üzerinde ilerlemek daha iyidir (Waldo, 1955:2-3).

D. Waldo eserde; yapısal-işlevselci ve kültürcü yaklaşımlardan faydalanılarak kamu kelimesinin anlamını ortaya koymaya çalışmaktadır. Yapısal-işlevselci yaklaşım farklı toplumları analiz ederek ortak yaşam alanının bir takım evrensel yönlerini saptamaya çalışmaktadır (Yalçın, 2010:49). D. Waldo bu yaklaşım kapsamında şu ifadelere yer vermektedir; "bir grubun kimliğiyle ilişsili olan, grup yaşamının bir bütün olarak özdeşleştirildiği kurumlar ve faaliyetlerin özel bir zorlayıcı, sembolik ve törensel yönleri vardır”, ifadesinde anlaşılacağı üzere bu yaklaşım, hükümetin belirli işlevlerinin kamu kalitesini anlamamıza yardımcı olur. Örneğin, suç işlemekle suçlanan kişilerin yakalanması ve yargılanması; mahkûmun cezalandırılması veya hapsedilmesi, paranın basılması ve kontrolü; dış ilişkilerin yürütülmesi, silahlı kuvvetlerin işe alınması, eğitimi ve kontrolü. Bu tür faaliyetlerin tekel bir yönü olmakla birlikte, özel olarak; özel şartlar, sembolizmler ve törenler ile donatılmıştır (Waldo, 1955:9). Eserde de belirtildiği üzere D. Waldo; bu yaklaşım çerçevesinde toplum mekanizmasından hareketle kamunun bazı yönlerini ortaya koymaktadır. Yapısal-fonksiyonel analiz, tekrarlayan fenomenlerle başa çıkmak için araçlar sağlar iken; kültür kavramı ise çeşitliliklerle başa çıkmak için araçlar sağlamaktadır. D. 
Waldo'ya göre kültür kavramı sosyal bilimlerde tüm inanç kompleksini ve toplumun yaptıklarını göstermek için kullanılmaktadır. Kültürün kurucu unsurları toplum veya topluluklar içinde değiştiği için yönetim, bu toplum veya toplumlar arasında rasyonel bir iş birliği eylemi sistemi olarak değişir. Diğer bir ifadeyle kamu kavramı farklı kültürlerde farklı anlamlar barındırmaktadır. Toplumlar arasında görülen kültürel farklılıklar kamu yönetiminin anlaşılması açısından önem arz etmektedir. D. Waldo’ya göre kamu kavramının tanımlanmasında işlevselci yaklaşım ve kültürel yaklaşımın bir bütün olarak ele alınması gerekmektedir (Waldo, 1955:11).

\subsection{Eserleri Bağlamında Dwight Waldo’ ya Yöneltilen Eleştiriler}

Genel itibariyle sorgulayıcı bir bakış açısıyla kamu yönetimine ilişkin kavramları, süreçleri, faktörleri eserlerinde analiz eden D. Waldo'ya yönelik birtakım eleştiriler bulunmaktadır. Örneğin; Richard Stillman tarafından sürekli soru sorduğu, kesin, net ve açık tanımlamalar yapmadığı, sorulara verdiği cevapların gerçeklere kısmen değindiği yönünde eleştirilmiştir (Özer, 2014:13). Bunun yanı sıra Brian R. Fry tarafindan kamu yönetimi alanında "yenilikçi - yaratıcı" bir etki bırakmasından ziyade, bir eleştirmen ve yorumcu olduğu yönünde eleştirilmiştir. Brian Fry; D. Waldo'nun bürokrasiye ve demokrasiye sahip olunması gerektiğini ancak ikisi arasındaki çatışmanın nasıl çözüleceğini ya da aradaki dengenin nasıl sağlanabileceğini belirtmemesini; kamu yönetiminin bir meslek olmadığını ifade etmesine rağmen, kamu yönetiminin meslek gibi faaliyette bulunmasını istemesini; yönetimin siyasete dahil olmasını savunmasına rağmen eserlerinde siyaset-yönetim ikiliğinde bazı değerlerin devam ettiği çıkarımlarında bulunarak D. Waldo'nun eserlerine ilişkin en büyük problemin onun kararsızlığı olduğunu belirtmektedir (Durmuş, 2017:434).

\section{KLASİK KAMU YÖNETIMINE ELEŞTİREL BİR BAKIŞ AÇISI: DWIGHT WALDO'NUN GÖRÜŞLERI}

D. Waldo tarafından ortodoks kamu yönetimi olarak adlandırılan geleneksel yaklaşımın dört temel öğretisi vardır; İlki siyaset ve yönetimin birbirinden ayrı olduğu varsayımıdır. İkincisi; yönetimin bir bilim olduğu fikridir. Üçüncüsü; yönetimin her yerde aynı olmasını savunan yönetimin bilimsel ilkelerinin var olduğudur. Son olarak; yönetimin birinci hedefinin verimlilik olduğudur. D. Waldo bu dört öğreti üzerinden geleneksel yaklaşıma ilişkin eleştirilerde bulunmaktadır (Kara, 2018:8).

\subsection{Siyaset- Yönetim Ayrımı}

Ona göre; geleneksel teorinin ileri sürdüğü siyaset- yönetim ayrımının amacı, 'demokrasi' ile 'verimlilik' arasındaki uzlaşının sağlanmasıdır. Bu noktadan hareketle karar verme -siyaset ve yürütme- yönetme olmak üzere devletin (dar anlamda) iki ana işlevi vardır. W. Wilson tarafından ileri sürülen yönetim-siyaset ayrımını D. Waldo, The Administrative State adlı eserinde eleştirmektedir (Atalay, 2008:154).

D. Waldo; "Kamu yönetimi teorisi, ister istemez bir politik teoridir de" saviyla yola çıkarak geleneksel kamu yönetiminin savunduğu kamu yönetiminin politikadan tamamen soyutlanması gerektiği düşüncesine karşı çıkmaktadır (McCurdy ve Rosenbloom, 2006:2'den akt.: Mijalıca, 2018:41). D. Waldo'ya göre yapıyı idari ve siyasi olarak ayırmaktan ziyade; başkanlık (presidential), sürekli kamu çalışanları ve bunların arasında sürekli değişen politik atanmışlar şeklinde ayrılması gerekmektedir. D. Waldo'nun böyle bir ayrımda bulunması ise siyaset ve yönetimi bir bütün olarak ele aldığının kanıtıdır (Sayman, 2006:31).

\subsection{Demokrasi ve Bürokrasi Karşıtlığı}

Weber bürokrasiyi "amaçlara ulaşmada en ussal ve etkin örgütlenme biçimi”" olarak tanımlamıştır. D. Waldo ise Weber'in bu tanımını eleştirerek bürokrasinin tüm amaçlar için en etkin örgütlenme biçimi olamayacağını ifade etmiştir (Atalay, 2008:145). D. Waldo'ya göre; apolitik ve tarafsız bir uzmanlar kadrosunun siyasetçilerin dolayısıyla onları seçen seçmenlerin kaygılarını ve değerlerini paylaşmayarak halkın taleplerini karşılaması demokrasinin ruhuna aykırıdır. Bu durum bürokratik seçkinciliğe neden olmaktadır. Bunun önüne geçebilmek için demokrasi anlayışının kamu kurumlarına nüfuz etmesi ve kurumların toplumsal sorunları çözme aşamasında yönetilenlerin rızasını gözetmesi gerekmektedir (Demir, 2011:70).

İdari Devlet adlı eserinde bürokrasi-demokrasi karşıtlığını siyaset-yönetim ayrılığı iddiası ile birlikte ele alarak bir sentez oluşturmaktadır. O bürokratik sistemin tamamıla demokrasi düşüncesiyle uyumsuz olduğu anlayış1 
kabul etmemektedir. Bürokratik sistemin apolitik, tarafsızlık özelliği ve uzmanlık, iş bölümü gibi işlevleriyle demokratik değerlerin uygulanmasına yardımcı olmaktadır. Ancak bürokratik sistemin uzmanlığa dayalı işlevi siyaset iktidarın rolünü çalma konusunda bir riskte oluşturabilmektedir. Bu husus demokrasi ve bürokrasi arasında optimal bir bileşim ortaya koyularak aşılabilir (Hatipoğlu, 2014:34).

\subsection{Olgu ve Değer İkilemi}

D. Waldo; olgu ve değer kriterlerini esas alarak kararları ikiye ayırmaktadır. Olgu kriterini esas alan kararların verimlilik ilkesi çerçevesinde verilebileceğini savunmaktadır (Atalay, 2008:171). D. Waldo; Demokratik Yönetim Kuramının Gelişimi adlı makalesinde karar verme durumunda değerlerin dışlanabilmesinin mümkün olmadığını, alternatifler arasında seçim yapmanın karar vermek anlamına geldiğini ve seçim yapmanın ise değerlerin göz önünde bulundurulmasını zorunlu kıldığını ifade etmektedir (Waldo, 1952:97).

D. Waldo'ya göre yönetim değer yüklü bir mekanizmadır. Bu açıdan, yönetsel gerçekliği anlayabilmek için katılan denekleri de içeren, gözleme dayanmayan ve deneysel bir sosyal bilim gereklidir. Bu yüzden D. Waldo mantıksal olgucu ve pozitivist bilimi reddetmektedir. Ayrıca D. Waldo; Simon'un olgu-değer ayrımına gitmesini eleştirmektedir. Simon olgu-değer ayrımından yola çıkarak araçlar ve amaçlar arasında ayrım olması gerektiğini savunmaktadır. Simon'a göre olgular, kamu yönetiminin(araç) alanında yer alırken; değerler ise siyaset (amaç) alanı içerisindedir. D. Waldo'ya göre demokratik yönetim sistemini sağlamak adına araç ve amaçların ortak olarak düşünülmesi gerekmektedir (Kara, 2018:13-17).

\subsection{Verimlilik ve Ekonomi}

Demokrasi-bürokrasi, siyaset-yönetim gibi ikilemler; kamu yönetiminin merkezinde yer alan verimlilik kavramı ekseninde oluşmaktadır. Demokrasiye ulaşmanın en önemli yolu verimliliktir. D. Waldo'ya göre verimlilik kendi içinde bir amaç değildir. Amaçlara ulaşmada bir araç görevi görmektedir. Waldo ekonomi ve verimlilik kavramlarıyla ilgili iki farklı görüşe atıfta bulunmaktadır. Birinci görüş; devletin minimalize edilmesini savunurken diğer görüş ise; ekonominin daha çok harcamakla, verimliliğin ise daha etkili ve büyük bir yönetsel mekanizmayla yürütülebileceğini savunmaktadır. D. Waldo’ya göre ikinci görüşün ileri sürdüğü teoriye karş1 çıkmanın mümkün olamayacağını ileri sürmektedir. D. Waldo'ya göre ekonomi ve verimlilik kavramları görmezden gelinemeyecek ölçüde toplumun ve siyasal yaşamla bütünleşmiştir (Atalay, 2008:201).

Kamu yönetiminde verimliliğin tek başına amaç olmasını eleştiren Waldo; İdari Devlet adlı eserinde yöneticilerin görevlerini etkin ve verimli bir şekilde gerçekleştirirken aynı zamanda demokratik değerlere uygun davranması gerektiğini dolayısıyla demokrasi ve verimlilik arasında çözümü olmayan bir çatışma olduğunu ileri sürmektedir (Demir, 2011:71).

\section{SONUÇ}

Amerika'nın içinde bulunduğu problemlerin aşılmasına yönelik ortaya çıkan YKYH kamu yönetimi disiplinine yeni bir kimlik kazandırmıştır. Her ne kadar bu hareket ABD ile sınırlı kalsa da kamu yönetiminde etik ilkelerin uygulanması, sosyal adalet ilkesine atıfta bulunması, demokratik yönetim anlayışını ön plana çıarması, siyasetyönetim ayrımına karşı çıkması açısından kamu yönetimi disiplinine katkıda bulunmuştur. Kamu yönetimine ilişkin bu adımların atılmasında D. Waldo'nun önemli bir rolü bulunmaktadır. D. Waldo 1968 yılında Public Administration Review'de yayınlanan "Public Administration in a Time of Revolutions" adlı eseri ile YKYH'nin başlangıç noktasını oluşturan Minnowbrook I konferansının toplanılmasını sağlamıştır. D. Waldo'nun doktora tezi yazım sürecinde gerçekleştirmiş olduğu çalışmaların kamu yönetimi disiplinine ilişkin görüşlerinin şekillenmesinde etkili olduğunu söylemek mümkündür.

D. Waldo; kamu yönetimine ilişkin birçok eseri literatüre kazandırmıştır. Klasik yönetimin temel savlarını eleştiren ve yönetim anlayışını yeni boyutlara taşıyan İdari Devlet; değerlerin göz ardı edilerek karar vermenin mümkün olmadığını savunan ve Simon-Waldo atışmasının başlangıcını oluşturan Demokratik Yönetim Kuramının Gelişimi adlı makale, kamu yönetimini hem bir süreç hem de bir disiplin olarak tasvir eden Kamu Yönetimi’nin İncelenmesi adlı eseri bunlardan bazılarıdır. Kamu yönetimine ilişkin değerleri, süreçleri, unsurları, tanımları sorgu ve analiz yöntemiyle ortaya koymaya çalışan Waldo sürekli soru sorduğu ve sorulara net cevaplar vermediği, açık tanımlamalar yapmadığı, yenilikçi çalışmalar ortaya koymaktan ziyade eleştirmen ve yorumcu 
olduğu yönünde eleştirilmiştir. Ancak, D. Waldo'ya yöneltilen bu eleştiriler onun düşüncelerinin tamamıyla yanlış olduğu sonucunu doğurmamaktadır.

Devlet mekanizması hem siyasal bir olgu hem de yönetsel bir olguyu temsil etmektedir. Diğer bir ifadeyle politik ile yönetsel süreç birbiriyle bağlantılı bir şekilde yürütülmekte ve bu süreçte erkler arasında işbirliği sağlanmaktadır. Günümüzde ise kamu yönetiminin yeni kimliklere bürünmesiyle birlikte (Yeni Kamu İşletmeciliği, Yeni Kamu Yönetimi gibi) bu süreçte demokrasi, yönetişim, verimlilik, hesapverilebilirlik, katılımcılık gibi unsurlar ön plana çıkmaktadır. Dolayısıyla D. Waldo'nun siyaset-yönetim ayrımına karşı çıkması, demokrasinin yönetim sürecinde aktif rol oynaması, bilimsel yönetim ilkelerini eleştirmesi, kuvvetler ayrılığı ilkesinin erkler arasında iş birliğini sağlaması yönündeki görüşlerinin geleneksel yönetim kalıplarını yıkarak günümüz kamu yönetimi anlayışına referans olduğunu söylemek mümkündür.

\section{KAYNAKÇA}

ATALAY, Mehmet (2008), “Kamu Yönetimi Disiplininde Dwight Waldo Düşüncesi”, Doktora Tezi, Ankara Üniversitesi Sosyal Bilimler Enstitüsü, Ankara.

ÇELİK, Süleyman (2010), “Kamu Politikası Analizinde Doğrusal Modelin Yetersizliği: Karmaşık Bir $\quad$ Model Önerisi”, Eskişehir Osmangazi Üniversitesi Sosyal Bilimler Dergisi, S.11(1), ss.217-234.

ÇIĞMAN, Muhammed Zahit (2015), “II. Meşrutiyet Türkiye’sinde Siyaset - Yönetim İlişkisi (1908 1914)”, Yüksek Lisans Tezi, İstanbul Üniversitesi Sosyal Bilimler Enstitüsü, İstanbul.

DEMIR, Fatih (2011), "Bürokrasi - Demokrasi İlişkisi ve Bürokratların Seçilmişlerce Kontrolü Sorunu", Yönetim ve Ekonomi Dergisi, S.18(2), ss.63-84.

DURMUŞ, Merve (2017), “Dwight Waldo Kamu Yönetimine Eklektik Bir Bakış”, Max Weber'den Dwight Waldo'ya Kamu Yönetimi (Ed. Oktay Koç), Anı Yayıncılık, Ankara, ss.401-455.

ERGUN, Turgay (1995), “Kamu Yönetimi Disiplininin Gelişmesine Kısa Bir Bakış: Yeni Arayışlar ve Gerçekler”, Kamu Yönetimi Disiplini Sempozyum Bildirileri I, TODAİE Yayınları, Ankara, ss.7-13.

FREDERICKSON, H. George (1989), “Minnowbrook II: Changing Epochs Of Public Administration”, Public Administration Review, S.49(2), ss.95-100.

GOODEN, Susan ve PORTILLO, Shannon (2011), "Minnowbrook III: A Special Issue Advancing Social Equity In The Minnowbrook Tradition", Journal of Public Administration Research And Theory, S.21, ss.i61-i76.

HATIPOĞLU, İbrahim (2014), “Tek Parti Döneminden Demokrat Parti Dönemine Bürokrasinin Değişimi”, Yüksek Lisans Tezi, Uludağ Üniversitesi Sosyal Bilimler Enstitüsü, Bursa.

HERGÜNER, Burak (2015), “Kamu Yönetiminde "Yeni” Kavramı ve Kamusal Tartışmalarla İlgisi Üzerine Bir Çalı̧̧ma”, Akademik Sosyal Araştırmalar Dergisi, S.(14), ss.73-84.

KARA, Evrim (2018), "Herbert Simon ve Dwight Waldo Karşılaştırması”, E-Makale, https://www.academia.edu/12391283/Herbert_Simon_ve_Dwight_Waldo_Kar\%C5\%9F\%C4\%B1la\%C5 $\% 9 \mathrm{Ft} \% \mathrm{C} 4 \% \mathrm{~B} 1 \mathrm{rmas} \% \mathrm{C} 4 \% \mathrm{~B} 1$ (Erişim Tarihi: 10.10.2018).

MIJALICA, Lorentina (2018), “Avrupa Birliği Üyeliği Sürecinde Kosova Kamu Yönetimi Reformu”, Yüksek Lisans Tezi, Gazi Üniversitesi Sosyal Bilimler Enstitüsü, Ankara.

OVEREEM, Patrick (2008), "Beyond Heterodoxy: Dwight Waldo and the Politics - Administration Dichotomy", Public Administration Review, S.68(1), ss.36-45.

ÖZER, Mehmet Akif (2014), "Kamu Yönetiminde Değişim Sürecini Dwight Waldo ile Yeniden Düşünmek”, Amme İdaresi Dergisi, S.47(4), ss.1-30.

ÖZGÜR, Hüseyin (2004), “Yeni Kamu Yönetimi Hareketi”, Çağdaş Kamu Yönetimi I (Ed. Hüseyin Özgür ve Muhittin Acar), Nobel Yayınları, Ankara, ss.183-216.

SAKLI, Ali Rıza (2013),"Kamu Yönetimi Disiplininde Bunalım Ve Çıkış Yolu Arayışları", Yüksek Lisans Tezi, Dokuz Eylül Üniversitesi Sosyal Bilimler Enstitüsü, İzmir.

SAYMAN, Coşkun (2006), "Dwight Waldo ve Yönetim Yazını”, Yüksek Lisans Tezi, Ankara Üniversitesi Sosyal Bilimler Enstitüsü, Ankara. 
STIVERS, Camilla (2008), "The Significance of The Administrative State”, Public Administration Review, S.68(1), ss.53-56.

TIMNEY, Mary (2009), “Parsing The 'Minnowbrook Tradition'”, Administrative Theory \& Praxis, S.31(1), ss.97-101.

TOZLU, Ahmet (2017), “Gerçek Yeni Kamu Yönetimi Hareketi Nedir?”, Türk İdare Dergisi, S.484, ss.331350.

WALDO, Dwight (1948), The Administrative State: A Study of The Political Theory of American Public Administration, Ronald Press Company, New York.

WALDO, Dwight (1952), "Development of Theory of Democratic Administration”, American Political Science Review, S.46(1), ss.81-103.

WALDO, Dwight (1955), The Study of Public Administration, Random House Inc., New York.

YALÇIN, Lütfi (2010), “Kamu Yönetimi Kuramlart: Yöntembilimsel Bir Değerlendirme”, Doktora Tezi, Ankara Üniversitesi Sosyal Bilimler Enstitüsü, Ankara. 